\title{
Nano Phytopathology-Exploring Future Opportunities in the Era of Climate Change
}

\author{
Aakanksha Kriti* \\ Department of Plant Pathology, Bihar Agricultural College, \\ BAU Sabour, Bhagalpur, Bihar, India
}

Keywords

Nanoparticle, Phytopathology, Disease, Antifungal activity, Climate

Article Info

Accepted:

15 January 2020 Available Online: 10 February 2020
A B S T R A C T

The changing global climatic scenario is a serious threat to the field of plant disease management. Reckless use of traditional agrochemicals is augmenting risks of environmental and ecological hazard with a negative impact on available resources in managing plant diseases. Frequent use of toxic agrochemicals poses threat not only to the abiotic components but also are of serious concern to the biotic factors of our ecosystem. The era demands incessant exploration in the innovative and opportunistic strategies which have greater impact with minimal use in eliminating plant diseases. Nanotechnology in the field of Phytopathology may be one among them to be explored in future for its specificity in effective plant disease management. Nanoparticle with its novel characters like low requirement, slow and persistent release and rapid fungicidal action may prove to be a unique way of controlling plant diseases with least disruption of our natural ecosystem.

\section{Introduction}

The issue of climate change raises questions on food security, environment and ecology across the world in the modern scenario. There exists tremendous pressure on exploring innovative tool to feed the ever increasing population with least adverse impact on climatic concerns. However the widespread and uncontrolled use of agrochemicals especially fungicides in plant health management has contributed significantly in deteriorating the quality of biotic as well as the abiotic components of our ecosystem.

Microorganisms undergo ceaseless evolution and adapt to new situations very rapidly (Harmon et al., 2009). Continuous use of fungicides potentially poses a risk to environment (Coakley et al., 1999). Under changed scenario, new races of pathogen evolve far more rapidly. However it takes quiet an appreciable period of time 
accompanied by an extensive research in developing newer and effective chemicals for arresting their growth.

Earlier, application of fungicides particularly $\mathrm{Cu}$ and Sulphur based was popularly practiced over traditional methods of plant health management owing to their rapid result. However concerns have now been raised over the long term use of these fungicides for their everlasting persistence that can result into toxicity of soil, water and plant health (Komárek et al., 2010).

Apart from the adverse impact on non-living components, these chemicals have found to be a major factor in elimination of beneficial microbial flora and fauna in soil. The need of hour is thus to innovate and strategies efforts in alternative ways of managing plant diseases. Nano Phytopathology could be one among them owing to the extraordinary characters of nanoparticles in managing plant health. Nanoparticles are of special interest due to their different properties compared with bulk.

properties (Banik et al., 2017). Presently, several of them are being explored for their antimicrobial effects (Ren et al., 2009; Jia et al., 2012). There exists thus a tremendous scope in analysing the novel mechanisms behind these nanoparticles which can significantly contribute to the field of plant health management in the forthcoming years.

\section{Different nanoparticle in phytopathology}

Recent era is a witness to the advancement made in the field of Nanotechnology. However the utilisation of novel characters of nanoparticles in arresting the microbial growth has shown some success in Plant health management too. Different types of nanoparticles are a subject of study for disease management.

\section{Nano copper and nano copper oxide}

Copper nanoparticles have been reported as effective antimicrobials in phytopathology (Cioffi et al., 2005; Ren et al., 2009; Jia et al., 2012).

The use of Nano Copper has found to be effective in controlling bacterial diseases viz. leaf spot of mung (X. Campestris $p v$. phaseoli), bacterial blight of rice (Xanthomonas oryzae pv. oryzae) (Gogoi et al., 2009). Further there has been scope for using Nano Copper oxides in providing greater protection to plants against late blight of tomato (Phytophthora infestans) and egg plant wilt (Verticilium dahlia) when compared to general practices.

Significant antifungal activity of Copper nanoparticles has been demonstrated against Phoma destructiva, Curvularia lunata, Alternaria alternata and Fusarium oxysporum (Kanhed et al., 2014).

Further, copper nanoparticles were found to inhibit the growth of fungal hyphae and conidial growth in Alternaria alternata and Botrytis cinerea (Ouda, 2014). Antifungal activity of copper nanoparticle responded to enhanced leaf yield of tea infected with $P$. hypolateritia (Ponmurugan et al., 2016). Slow and persistent release of carbon nanoparticles provides an opportunity for its better exploration in the field of plant health management.

\section{Nano silver}

Ionic silver has long been used for killing unicellular microorganisms (Thomas and McCubin, 2003). Extensive research work is therefore under process for enhancing the efficacy of silver nanoparticle as antifungal/ antimicrobial agent. 
Antifungal activity of silver in managing plant diseases has been tested against Bipolaris sorokiniana in Wheat, Magnaporthe grisea in rice (Jo et al., 2009) and Sphaerotheca pannosa var. rosae in rose (Sharon et al., 2010). Park et al., (2006) found silver nanoparticle of size $10 \mathrm{ppm}$ to inhibit vegetative growth of fungi and also effective against several bacterial pathogens.

Silver nanoparticle upon accumulation in fungal hyphae of Bipolaris sorokiniana, Magnaporthe oryzae and Colletotrichum gloeosporioides can provide greater protection to plants due to cellular disruption of fungi.

Nano silver was shown to possess antifungal activity against Sclerotium-forming phytopathogens, Rhizoctonia solani, Sclerotium sclerotiorum and Sclerotium minor (Min et al., 2009) as well as against Pythium sp, Colletotrichum sp, Xanthomonas campestris etc. (Park et al., 2006).

Antimicrobial activity of nano silver has been further explored against Cladosporium cladosporioides, Aspergillus niger (Pulit et al., 2013) and Botrytis cinerea (Ouda, 2014).

\section{Nano carbon}

Nano Carbon of various shapes like nanohorns, nano-cones, fullerenes, carbon dots, nano-beads etc. have exhibited greater potentiality in controlling fungal growth as compared to their bulk counterpart. Nano Carbon encapsulated fungicides have shown greater degree of toxicity to Alternaria alternata (Sarlak et al., 2014).

Another study revealed greater degree of microbial inactivation in Fusarium graminearum and Fusarium poae upon application of carbon nanotubes as against broad spectrum fungicides (Zaytseva et al.,
2016). Stronge antifungal activity of nano carbon was explored in Ralstonia solanacearum, Fusarium oxysporum (Wang et al., 2013).

\section{Nano zinc}

Zinc is one of the essential micronutrients utilised by plant. It is a key constituent of several enzymes and proteins. Zn nanoparticle has been reported to enhance seed germination and seedling growth. However in another experiment zinc nanoparticle was found to exhibit greater inhibitory potential against several fungi and bacteria Staphylococcus aureus (Sabir et al., 2014).

\section{Nano iron}

There has been little experimental investigation on revealing the inhibitory potential of nano iron in phytopathology. Corredor et al., (2009) applied carbon coated iron nanoparticle to infected pumpkin that showed some optimistic results. Targeted delivery of iron nanoparticle for managing health of plant is still under infant stage and research is being undertaken to make it possible in forthcoming days.

\section{Future prospects of nanoparticle in} phytopathology

Recent regime invites innovative set of practices for better management of phytopathological diseases that will cause least disruption of natural climatic conditions. Better environment friendly approaches need to be stressed to regulate the infective behaviour of microorganisms in minimum possible time with maximum possible outcome simultaneously.

Nanoparticles differ significantly with their bulk counterpart in terms of specificity, rapid action, targeted delivery, slow and controlled 
release, lesser toxicity and least requirement for maximum result. They can be used directly as antimicrobial agent, act as carriers or even as encapsulating material for fungicides.

The ever increasing population already is a threat to the limited resources prevailing on our planet paving scope for novel strategies to be incorporated in controlling phytopathological diseases. There exists tremendous scope for unfolding the novel mechanisms in exploring nanoparticle for its better and effective use in the field of plant health management, simultaneously taking into account the hot debate on climatic concerns.

Table.1 Different nanoparticles and pathogens inhibited

\begin{tabular}{|c|c|c|}
\hline Sl. No. & Nanoparticles & Pathogens controlled \\
\hline a & Copper & $\begin{array}{l}\text { Xanthomonas campestris pv. phaseoli, } \\
\text { Xanthomonas oryzae pv. oryzae, } \\
\text { Phytophthora infestans, } \\
\text { Verticilium dahlia, } \\
\text { Phoma destructiva, } \\
\text { Curvularia lunata, } \\
\text { Alternaria alternata, } \\
\text { Fusarium oxysporum } \\
\text { Botrytis cinerea }\end{array}$ \\
\hline b & Silver & $\begin{array}{l}\text { Bipolaris sorokiniana, } \\
\text { Magnaporthe grisea, } \\
\text { Sphaerotheca pannosa var. rosae } \\
\text { Colletotrichum gloeosporioides, } \\
\text { Rhizoctonia solani, } \\
\text { Sclerotium sclerotiorum, } \\
\text { Sclerotium minor, } \\
\text { Pythium sp, } \\
\text { Colletotrichum sp, } \\
\text { Xanthomonas campestris, } \\
\text { Cladosporium cladosporioides, } \\
\text { Aspergillus niger }\end{array}$ \\
\hline c & Carbon & $\begin{array}{l}\text { Alternaria alternata, } \\
\text { Fusarium graminearum, } \\
\text { Fusarium poae, } \\
\text { Ralstonia solanacearum, } \\
\text { Fusarium oxysporum }\end{array}$ \\
\hline d & Zinc & Staphylococcus aureus \\
\hline
\end{tabular}

Nano encapsulated fungicides may be helpful in targeted delivery, thus enhancing its specificity. In-vitro experiments conducted recently have shown appreciable results in managing plant diseases by arresting growth of microbes particularly fungi. Several of them were shown to have resisted the vegetative growth of fungus prolonging the approach of infection. 
Additionally, Government should stress and promote the funding as well as research and extension work related to the novel mechanisms that are fundamental and far more implicit in better exploration of nanoparticle in the field of phytopathology in the era of climate change. Future thus has inherent opportunities in prospecting nanophytopathology.

\section{References}

Banik S, Pérez-de-Luque, A. (2017). In vitro effects of copper nanoparticles on plant pathogens, beneficial microbes and crop plants. Spanish journal of Agri Res 15(2), e1005.

Cioffi N, Torsi L, Ditaranto N, Tantillo G, Ghibelli L, Sabbatini L, Bleve-Zacheo T, D'Alessio M, Zambonin PG, Traversa E. (2005). Copper nanoparticle/polymer composites with antifungal and bacteriostatic properties. Chem Mater, 17: 5255-5262.

Coakley SM, Scherm H , Chakraborty S. (1999). Climate Change and Plant Disease management. Annual Review of Phytopathology, 37: 399-426.

Corredor E, Testillano PS, Coronado MJ, González-Melendi P, Fernández PR, Marquina C, Ibarra MR, de la Fuente JM, Rubiales D, Pérez-de-Luque A, Risueño MC. (2009). Nanoparticle penetration and transport in living pumpkin plants: in situ subcellular identification. BMC Plant Biology 9:45.

Gogoi R, Dureja P, Singh PK. (2009). Nanoformulations-a safer and effective option for agrochemicals. Indian Farming, 59(8): 7-12.

Harmon JP, Moran NA, Ives RA. (2009). Species Response to Environmental Change: Impacts of Food web Interactions and Evolution. Science, 323:134A.

Jia B, Mei Y, Cheng L, Zhou J, Zhang L.
(2012). Preparation of copper nanoparticles coated cellulose films with antibacterial properties through one-step reduction. ACS Appl Mater Interfaces, 4: 2897-2902.

Jo YK, Kim BH, Jung G. (2009). Antifungal activity of silver ions and Nanoparticles on Phytopathogenic Fungi. Plant Dis. 93(10): 1037-43.

Kanhed P, Birla S, Gaikwad S, Gade A, Seabra AB, Rubilar O. (2014). In vitro antifungal efficacy of copper nanoparticles against selected crop pathogenic fungi. Materials Letters, 115: 13-17.

Komárek M, Čadková E, Chrastný V, Bordas F, Bollinger JC. (2010). Contamination of vineyard soils with fungicides: a review of environmental and toxicological aspects. Environ Int, Jan;36(1): 138-15.

Min JS, Kim KS, Kim SW, Jung JH, Lamsal K, Kim SB, Jung MY, Lee YS. (2009). Effects of colloidal silver nanoparticles on Sclerotium-forming phytopathogenic fungi. The Plant Pathology Journal, 25(4):376-380.

Ouda SM. (2014). Antifungal activity of silver and copper nanoparticles on two plant pathogens, Alternaria alternata and Botrytis cinerea. Res Journal of Micob, 9(1), 34-42.

Park HP, Kim SH, Kim HJ, Choi HS. (2006). A New composition of Nanosized silica-silver for Control of various Plant Diseases. Plant Pathol. J. 22(3): 295302.

Ponmurugan P, Maniukarunambika K, Elango $\mathrm{V}$ (2016). Antifungal activity of biosynthesized copper nanoparticles evaluated against red root-rot disease in tea plants. Journal of Expt Nanoscience 11(13), 1019-1031.

Pulit J, Banach M, Szczglowska R, Bryk M (2013). Nanosilver against fungi: Silver nanoparticles as an effective biocidal 
factor. Acta Biochimica Polonica, 60: 795-798.

Ren G, Hu D, Cheng EWC, Vargas-Reus MA, Reip P, Allaker RP. (2009). Characterisation of copper oxide nanoparticles for antimicrobial applications. Int J Antimicrob Agents, 33: 587-590.

Sabir S, Arshad M, Khalil C. (2014). Zinc oxide nanoparticles for revolutionizing agriculture: Synthesis and applications. The Scientific World J, 2014:1-8.

Sarlak N, Taherifar A, Salehi F. (2014). Synthesis of nanopesticides by encapsulating pesticide nanoparticles using functionalized carbon nanotubes and application of new nanocomposite for plant disease treatment. J Agric Food Chem 62:4833-4838.

Sharon M, Choudhary AK, Kumar R. (2010).
Nanotechnology in agricultural diseases and food safety. J. Phytology 2(4): 8392.

Thomas S., McCubin P. (2003). A comparison of the antimicrobial effects of four silver containing dressings on three organisms. J. Wound Care., 12: 101-107.

Wang L, Fortner JD, Hou L, Zhang C, Kan AT, Tomson MB, Chem W (2013). Contaminant-mobilizing capability of fullerene nanoparticles (nC60: effect of solvent-exchange process in $\mathrm{Nc60}$ formation. Environ Toxicol Chem 32:329-336.

Zaytseva O, Neumann G. (2016). Carbon nanomaterials: production, impact on plant development, agricultural and environmental applications. Chem Biol Technol Agric 3:17.

\section{How to cite this article:}

Aakanksha Kriti . 2020. Nano Phytopathology- Exploring Future Opportunities in the Era of Climate Change. Int.J.Curr.Microbiol.App.Sci. 9(02): 1984-1989. doi: https://doi.org/10.20546/ijcmas.2020.902.226 